\title{
Stories we live, identities we build: how are elementary teachers' science identities shaped by their lived experiences?
}

\author{
Lucy Avraamidou ${ }^{1}$
}

Received: 17 February 2017/Accepted: 14 November 2017/Published online: 20 February 2018

(C) The Author(s) 2018. This article is an open access publication

\begin{abstract}
The aim of this multiple case study was to uncover a series of critical events and experiences related to the formation of the science identities of four beginning elementary female teachers, through a life-history approach and a conceptualization of teacher identity as lived experience. Grounded within the theoretical framework of Figured Worlds, the study used qualitative, interpretive methods for data collection (interviews, biographies, teaching philosophies) and analysis. The analysis shed light on the ways in which various experiences situated within different Figured Worlds (science, family and childhood, schooling, out-of-school, university, professional) impacted the participants' identity trajectories. The findings provided three main insights that contribute to science identity research and have implications for elementary teacher preparation: (a) science teacher identity is multidimensional and extends beyond cognitive domains of becoming to include affective dimensions; (b) science teacher identity is relational, linked and shaped by various other constructs or sub-identities; (c) place and time, defined as a space with meaning created by experiences, and science teacher identity are inextricably bound to one another.
\end{abstract}

Keywords Science identity · Lived experience $\cdot$ Life-history $\cdot$ Teacher preparation

In August 2015, the Science Education for Responsible Citizenship report was published, which offers a twenty-first century vision and the role of science education, within the European agenda promoting a science for society paradigm (European Commission 2015). The main objectives and recommendations of the report suggest linking science with other

Lead editor: A. Oliveira.

Lucy Avraamidou

L.Avraamidou@rug.nl

1 Institute for Science Education and Communication, University of Groningen, Groningen, The Netherlands 
subjects and disciplines, enhancing the quality of teaching, promoting the collaboration between formal, non-formal, and informal education, enhancing public understanding of scientific findings, and connecting science education strategies at local, regional, national, European and international levels. These objectives and recommendations reflect how global competition and technological development as well as societal challenges (i.e., migration), place new demands and raise high expectations of science education. For example, migration causes demographic changes in local populations, which in turn call for attention to diversity and inclusion given that a democratic future depends on whether all people are offered exciting opportunities to engage with science and become active consumers of scientific information. To meet these challenges, the field of science education is required to make significant transformations on different levels including policy, curriculum, research, teacher preparation, and practice.

For teacher preparation and professional development, these transformations call for comprehensive, multi-faceted, dynamic, and multidimensional theoretical constructs to frame teacher learning and development. Such a comprehensive framing can be found within the construct of teacher identity, which, as evident in related literature, offers a powerful, comprehensive and multidimensional lens to studying science teacher development, which goes beyond cognitive aspects of learning (Avraamidou 2014, 2016a; Varelas 2012). As Luehmann (2008) argued, the construct of identity is particularly important within the field of teacher education because it offers a comprehensive construct for studying teacher learning and development, which goes beyond knowledge and skills:

The sole focus on knowledge, understanding or other purely cognitive constructs in teacher education, has been criticized as limited as it leaves the novice teacher alone to figure out how to develop, integrate, and reconcile emotions and physical aspects with the understandings involved in becoming a teacher. (p. 827)

Researchers have viewed science teacher identity in terms of how teachers view themselves and are recognized by others (Gee 2000); the stories that teachers create and tell about their teaching lives (Connelly and Clandinin 1999); the communities in which teachers participate, learn and develop (Wenger 1998); gender perspective (Carlone and Johnson 2007); and, through a positionality lens (Moore 2008). Despite the different ways in which science identity has been conceptualized and studied, there exists a consensus in the literature about the usefulness of the construct of identity in studying teacher learning and development given its multidimensional nature (Avraamidou 2014). The construct of identity is greatly important especially when studying women's engagement with science, given that identity offers itself as a tool for examining the ways in which gender identity might influence how women see themselves as science persons. This is significant based on the fact that women are underrepresented in the sciences and there exists a lack of diversity in scientific fields (UNESCO 2015).

In a review study on science teacher identity, I had argued that the knowledge base includes information about approaches and interventions that might support teachers in developing science identities throughout teacher preparation and professional development, however, missing remains an understanding about beginning teachers' identities as they enter teacher preparation (Avraamidou 2014). In attempting to contribute to this gap in the literature, the purpose of this study was to examine a group of beginning female teachers' development of science identities through time and across contexts. More specifically, through the use of a life history approach, the aim of this study was to uncover events and experiences of the participants' lives that were critical to the development of their science identities. For the purpose of this study, identity is conceptualized as a lived 
experience, shaped within multiple contexts, and attention is paid to the processes of becoming a science teacher. As such, the main research questions that guided this study were the following:

(a) How do beginning elementary female teachers make meaning of their lived science experiences in various contexts from their childhood to their professional lives?

(b) How are beginning elementary female teachers' science identities mediated and shaped by their lived experiences?

\section{Identity as a lived experience}

This study is concerned with teachers' narratives that tell stories of becoming teachers, essentially, stories of forming science identities. These narratives are examined through a biographical lens, a life history approach. As such, the study is theoretically grounded within Jean Lave's and Etienne Wenger's (1991) view that “one way to think of learning is as the historical production, transformation, and change of persons" (pp. 51-52). In viewing teachers' learning as identity development, I am especially interested in how different experiences situated in various contexts or communities impact their identity development. To conceptualize these various contexts, I use Dorothy Holland's and her colleagues (1998) model of Figured Worlds as an analytical framework. As they described:

Figured Worlds take shape within and grant shape to the coproduction of activities, discourses, performances, and artifacts. A Figured World is peopled by the figures, characters, and types who carry out its tasks and who also have styles of interacting within, distinguishable perspectives on, and orientations toward it (p. 51).

The Figured-Worlds perspective turns our attention to the contexts of meaning that teachers make, and how they come to construct identities by placing themselves and their actions in relation to activities situated in specific contexts. As such, it provides a useful framework for examining how teachers participate in various contexts across time, and how their participation impacts their identity formation. These Figured Worlds feature as the central unit of analysis in this study as they provide the "contexts of meaning for actions, cultural productions, performances, disputes, for the understandings that people come to make of themselves, and for the capabilities that people develop to direct their own behavior in these worlds" (p. 60). Hence, for the purpose of analyzing the data, in this study, I view teacher science identity as consisting of various Figured Worlds: family and childhood, schooling, outside-of-school, university, science, professional experiences.

Situated within various Figured Worlds, I conceptualize identity as a lived experience (what Vygotsky referred to as perezhivanie) which presents a dynamic, fluid and complex unit of analysis between personality characteristics and environmental characteristics. Lived experience is used to emphasize how: (a) cognition/thinking/meaning are inextricable from feelings/emotions/sense; and, (b) learning and experience are intrinsically situated in a matrix of life trajectories and ecological, transactional aspects throughout one's life (Esteban-Guitart and Moll 2014). In doing so, in this study I aim to uncover critical events that the participants have experienced through their participation in various Figured Worlds, to elucidate the meaning that they assigned to those events, and to explore the ways in which those events impacted the development of their science identities or how the participants viewed themselves and their roles as science teachers. Gaining an 
understanding about these events, experiences, and interactions as well as the contexts in which they occur, can provide useful insights and serve as input for the design of teacher preparation programs that aim at supporting elementary teachers' re-construct their science identities.

\section{What constitutes science teacher identity and what impacts its development?}

In a review study on teacher identity, covering the period of 1988-2000, Douwe Beijaard, Paulien Meijer and Nico Verloop (2004) identified the following features as essential for teachers' professional identity:

- Identity is an ongoing process of interpretation and re-interpretation of experiences

- Identity implies both person and context

- Identity consists of sub-identities

- Agency is central, which refers to the need of teachers being active in the process of professional development (p. 122).

These insights have been used by a few researchers in the field of science education who explored the what and how questions referring to the main dimensions of a science teacher identity and how its development can be supported.

One approach to mediating teachers' development of identities is found within collaborative teaching experiences and reflexive dialogues, proposed by Christina Siry and Johaira Lara (2012) based on the finding of their study with a pre-service teacher participating in a field-based science methods course in New York. In analyzing the videotaped course sessions and co-generative dialogues in the context of this methods course, the authors focused on specific events in Johaira's life as a participant in the course that provided her with resources to understand herself as a teacher differently. As the findings of this study showed, Johaira entered the course with traditional views of teaching, which were shifted to more contemporary and innovative views of science teaching, because she was provided with opportunities to examine her epistemological perspective on teaching and science through co-generative dialogues in the context of a methods course.

Other researchers have examined the ways in which out-of-school experiences support teachers' science identity development. For example, Phyllis Katz (2011) explored the ways in which an afterschool informal internship supported prospective elementary teachers' professional identity development. The findings of this study showed that the participants were able to see themselves as enacting key reform recommendations including: positive attitudes, sensitivity to diversity, facilitating hands-on science participants, inquiry and collaborative work. Another approach to supporting teachers' identity development is the use of apprenticeship programs with scientists, proposed by Maria Varelas and her colleagues. In their study with three beginning teachers enrolled in a summer apprenticeship at a science laboratory, Varelas et al. (2005) showed that as the participants engaged in science apprenticeships they developed understandings about the practice of science and the work of scientists as a community of practice. Specifically, the participants came to appreciate important standard practices, speech acts and tools of scientific activity that indicate salient elements of their science identities.

Apart from examining approaches to support teachers' science identity development, other researchers examined specific aspects or dimensions of a science teacher's identity. 
For example, Jenifer Helms (1998) argued that understandings and beliefs about the nature of the subject matter is a major component of a science teacher's identity. Other researchers, including myself (Avraamidou 2016b), have provided evidence through a series of qualitative studies about the impact of the context on a teacher's identity. For example, context featured centrally in Gail Richmond's (2016) study in which she explored the interplay between professional identity and contextual factors, and how these contribute to a sense of agency. Using interviews, journals, course and field assignments and related artifacts, Richmond examined how science teacher candidates preparing to work in high-poverty schools in the United States, make sense of their multiple contexts, and how this sense-making shapes their professional identity and agency as science educators committed to working in challenging settings. The findings of this study showed that: (a) the consonance between the professional identity one sculpts and the agency one has for making intentional moves likely to have positive outcomes, are critical in creating the conditions for success, in the near and distant future; and, (b) contextual factors matter, not only for that sense of agency to develop initially, but to be maintained. The impact of the context on teachers' development of identities has also been documented in Bhaskar Upadhyay's (2009) study, which examined the impact of a high-stakes test environment on an elementary teacher's science identities. In a period of 2 years, 10 science lessons were videotaped and eight interviews were conducted with the participant. The analysis of these data illustrated how the participant experienced many dilemmas and tensions while teaching science in a school that emphasized high-stakes testing and mostly served students from poor and minority families. However, as Upadhyay demonstrated, the participant negotiated her personal and professional identities in a constraining classroom environment. The findings of this study provide evidence of how identities, teaching practices, teaching dilemmas, and negotiations of those teaching dilemmas and identities are interrelated and influenced by the context in which they take place.

In addition to the context and the sense of agency, another important dimension of science identity is positionality. As Felicia Moore (2008, 2016) argued, positional identity (defined in terms of social markers such as race, ethnicity, etc.) is important to gaining a deeper understanding of identity when it involves teachers of color and studying science teacher identity. Felicia Moore (2016) examined how ten female elementary preservice teachers of color, in the context of a 16-week graduate level elementary methods course, developed their identities. Data were collected through the participants' responses to preand post-questionnaires on the first and last day of the course. The analysis of these data showed that the most common descriptions related to why the participants saw themselves as teachers were: (a) having previous experiences, though not necessarily in teaching, such as playing the teacher as a young child, or having previous career experience, for instance, journalism; (b) having student teaching experiences; (c) working with young people or adults; and, (d) being seen by others as a teacher. These findings point to the importance of looking closely at the incoming views that preservice teachers of colors have about science teaching and how race/ethnicity intersects with other social markers in teacher education.

Related to positionality is the construct of emotions and social justice, another major dimension of a teacher's science identity, which has been studied by Maria Rivera Maulucci (2013) as well as Kenneth Tobin and Reynaldo Llena (2012). Building upon the idea of social justice Maria Rivera Maulucci (2013) argued that emotions are central mediators of teachers' identities for social justice. In a study with an African-American Caribbean preservice teacher, she explored the historical development of this teacher's social justice stance. With the use of various biographical data (i.e., response to prompts, essays, assignments and an interview collected over one semester), she examined why the 
participant decided to become a Chemistry teacher, and she showed how the participant's emotions shaped her science identity and positioned her in relation to issues of justice, and her struggles with notions of oppression and multicultural education.

A related line of research lays at the intersection of life-histories and science identities (Eick and Reed 2002). In a previous study, published in 2014, I examined the impact that various experiences with science had on a beginning elementary teacher's (Maria) development of identity for science teaching. With data gathered over a period of 5 years, I showed how the participant constructed and reconstructed her science identity based on the various experiences she had with learning, learning-to-teach and teaching science in various contexts, ranging from elementary school, to university and the first year of teaching. The findings of this study showed that Maria had positive experiences as a learner of science at elementary school, however, she lost interest in science in middle school through high school because of negative experiences with science instruction and instructors. Her interest in science was re-kindled when she went to university, where she had positive experiences and critical interactions with young, female, science instructors, which might suggest the role of gender in the development of a science identity. This current study follows up on these findings to examine how the life histories of four beginning female elementary teachers with a range of teaching experiences ( $0-5$ years) intertwine with their science identities.

By examining the life histories of this group of beginning elementary teachers this study adds to existing knowledge base about teachers' science identities, but it also addresses two gaps in the literature: (a) there is a limited number of studies in elementary education, especially with beginning teachers; and (b) there are very few studies that examine how teachers develop their science identities throughout their lives. As a matter of fact, with the exceptions of Felicia Moore's $(2008,2016)$ and my own (2016b) studies, there are no other studies situated in the elementary context that examine teachers' science identities through a life history lens. It is at the intersection of this literature on beginning female elementary teachers' science identities formation and what might influence the shaping of their identities, that this study seeks to make a contribution. Unlike previous single case studies on identity and life history, this multiple case study presents data about four beginning female teachers' identities and life histories, and it offers opportunities for comparing and contrasting cases. This study aims at making a unique contribution to the literature by proposing a set of dimensions of a science teacher's identity drawn upon the outcomes of this study, and which could be used as a theoretical and methodological springboard by other researchers examining science teacher identity development as well as input for teacher preparation.

\section{The where and how of the study}

The context of this study is framed by a graduate program in science education at a private university in a Southern European country following a two-semester and a summer semester academic calendar. Each course of this Master's program is 13-weeks long and includes three instructional hours per week. The title of the course in which the participants were enrolled at the time this study took place was titled "Contemporary Approaches to Science Teaching and Learning". The course is designed upon recommendations for reform, especially in the context of the framework Science Education for Responsible Citizenship (EC 2015) as described in the introduction. As such, the course 
places emphasis on how science connects to society through the use of innovative instructional approaches. As part of the course, participants were provided with multiple opportunities to examine and re-examine their developing science identities. These include activities in the classroom as well as course assignments which aim at providing participants with opportunities to reflect on their prior experiences with science, to reexamine their science identities and to reflect on their ideas about the purpose of teaching science at elementary school, their roles as science teachers, as well as their ideas about science teaching and learning. This is done specifically through the following assignments: (a) a personal life-story in relation to science, where teachers are asked to provide a description of their life experiences with science; (b) drawing assignments alongside justifications of best and worst science experiences; (c) a self-portrait alongside a justification where teachers are asked to draw how they view themselves in the science classroom; and, (d) a personal philosophy essay, where teachers are asked to share their views about how children learn science best and to explain why. In addition, the course included multiple activities aimed at supporting teachers' development of science identities, drawn out of related studies described earlier, as for example: whole-classroom discussions about how they view themselves as science teachers, video-based lesson analysis, and an out-of-school experience that provided the opportunity to work closely with a scientist.

This study is designed as a qualitative multiple case-study given that each participant (Maria, Emily, Jennifer, and Lisa — all pseudonyms) serves as an individual case study, and uses detailed, in-depth data collection involving multiple sources of information (i.e., assignments, interviews, lesson plans, reflective journals) (Merriam 2009). All four participants were female, middle-class Caucasians, between 22 and 30 years old, two of whom had specialized in science during their preparation. At the time they entered this study, the participants, as a group, had a range of teaching experiences, from 0 to 5 years, and illustrated a range of content knowledge, views about teaching, attitudes and orientations toward science and science teaching, as evident in their science-courses grades and assignments. At the time of the study all participants were in their first-year (of the two in total) of a graduate Master's program in science education. These four women were chosen because I assumed that their diverse characteristics (as a group) would lead to main assertions, even though not generalizable in the conventional paradigm, about beginning female elementary teachers' formation of science identities. What makes these participants unique cases is that they were all positively positioned towards science and science teaching at the time they graduated from university.

Several kinds of data were collected for each participant for the purpose of this study: a detailed science-biography (8-10, A4-pages), a personal philosophy statement (5-8, A4pages) and a 2-h long interview with each of the participants. The data were collected over a period of a year during which the participants were enrolled in the Master's program. The biographies and personal philosophies were collected as part of the assignments of the science course (after the course was over to avoid bias) and the interviews were conducted after the course was completed and the participants had received their grades and agreed to participate in the study. To analyze the data, I first organized those based on the two research questions: data that would help me characterize the nature of the participants' science identities and data that would help me examine the impact of various experiences the participants had throughout their lives on the development of their identities. For the analysis of the data, I used in vivo, line-by-line coding techniques (Corbin and Strauss 2008) and so the codes were taken from the content of the data or the exact words of the participants. Examples of open codes include the following: family relationships, 
childhood experiences, influence of parents, outdoor experiences, school experiments, teachers' personalities, teachers' teaching style, relationships with teachers, nature of the classroom environment, excitement, disappointment, self-efficacy, university coursework, inquiry-based science, role-models, women in science, etc. Following the open-coding processes, I looked for patterns into the data in order to develop subcategories and categories. Examples of sub-categories that emerged from the analysis are the following: childhood aspirations, influences within the family/childhood figured world, sense of competence as a science learner, influences within the figured world of schooling, the personal stance towards science, shifts on positioning, gender, a sense of agency, the emotional trajectory, a rich/limited subject-matter knowledge, views about science teaching and learning, etc. In grouping the sub-categories, main conceptual categories were developed, and based on these the findings are presented next: a sense of self, gender, positioning towards science teaching, agency, emotions, subject-matter knowledge, and a personal philosophy of teaching. These are, in fact, the main dimensions that emerged from the participants' identities, as will be discussed later on. Table 1 provides an example of the main categories and subcategories as constructed through the analysis.

In pursuit of establishing trustworthiness I used triangulation strategies through the following: (a) collection of data for the same purpose (e.g., to examine biographical information) from various sources (i.e., a drawing activity, a written narrative and an interview); (b) member check from the participants and an external researcher to reduce a possible bias on my behalf as a researcher and instructor. Specifically, I had asked all participants to read my narration of their personal story in relation to science and to point to any inconsistencies. In addition, I had asked an external researcher who is familiar with the context of the study to code randomly selected data (about 30\%) with the use of the coding scheme that I had developed. Following that, we discussed our analyses until we came to an agreement and the coding scheme was revised accordingly.

\section{Exploring the participants' life histories as a way of capturing their developing science identities}

\section{Maria}

Maria is 24 years old and is a first-year elementary teacher with a specialization in science. Within the Figured World of science, she is positioned positively towards science and science teaching. As she said in the interview, becoming a teacher was the "dream of her life". Elaborating on the reasons why she likes science she stated: "Because it's about understanding how the world works! Science excites me". Describing her science experiences within the Figured World of childhood and family, she shared many memories of herself in nature working in her grandparents' farm, which as she described in her autobiography, made her "develop an admiration about the natural world and how it works". When asked to elaborate on this, Maria noted the great impact of her parents who are also science teachers and for whom she holds great respect. This is important because it provides evidence that family capital is an important factor to the development of a strong science identity.

Situated in the Figured World of out-of-school science, Maria described the following event as the most influential science learning experience she had: 
Table 1 Data analysis

\begin{tabular}{|c|c|c|}
\hline Figured world & $\begin{array}{l}\text { Identity } \\
\text { dimension }\end{array}$ & Samples of data \\
\hline \multirow[t]{4}{*}{ Science } & Sense of self & I was always into science (Maria, autobiography) \\
\hline & Positioning & $\begin{array}{l}\text { Science is so important because it's about understanding how the } \\
\text { world works (Maria, interview) }\end{array}$ \\
\hline & Gender & $\begin{array}{l}\text { I remember visiting my aunt, who was a geologist, at work... she was } \\
\text { a role model for me! (Jennifer, interview) }\end{array}$ \\
\hline & Emotions & $\begin{array}{l}\text { It was an amazing experience because we worked with scientists } \\
\text { (Maria, interview) }\end{array}$ \\
\hline \multirow{4}{*}{$\begin{array}{l}\text { Childhood- } \\
\text { family }\end{array}$} & Sense of self & I felt confident in doing science (Maria, autobiography) \\
\hline & Positioning & $\begin{array}{l}\text { For as long as I can remember, I have always wanted to become a } \\
\text { teacher because my mother is a school-teacher (Lisa, } \\
\text { autobiography) }\end{array}$ \\
\hline & Gender & $\begin{array}{l}\text { My friends thought that my interests were weird so I felt different } \\
\text { because girls don't play with the soil (Emily, autobiography) }\end{array}$ \\
\hline & Sense of self & $\begin{array}{l}\text { I am interested in science because of the science documentaries that I } \\
\text { used to watch (Emily, autobigraphy) }\end{array}$ \\
\hline \multirow[t]{2}{*}{ Out-of-school } & Positioning & $\begin{array}{l}\text { We visited an environmental center...it was an amazing experience. } \\
\text { It made me love science and admire scientists even more. (Maria, } \\
\text { interview) }\end{array}$ \\
\hline & Emotions & $\begin{array}{l}\text { One of my most memorable experiences with science was a visit to a } \\
\text { science center with my family. I was so excited. (Lisa, } \\
\text { autobiography) }\end{array}$ \\
\hline \multirow[t]{3}{*}{ Schooling } & $\begin{array}{r}\text { Sense of self } \\
\text { Positioning }\end{array}$ & $\begin{array}{l}\text { I was one of the best students in all science classes throughout my } \\
\text { schooling years (Maria, autobiography) } \\
\text { Physics and biology were my favorite subjects in school (Emily, } \\
\text { autobiography) }\end{array}$ \\
\hline & Gender & $\begin{array}{l}\text { He was an older man, wearing very big glasses and overall he had a } \\
\text { messy look (Jennifer, interview) }\end{array}$ \\
\hline & Emotions & $\begin{array}{l}\text { I was happy to be in his class and excited to engage in the activities } \\
\text { (Emily, interview) }\end{array}$ \\
\hline \multirow[t]{4}{*}{ University } & Gender & $\begin{array}{l}\text { A university instructor stands out for me and will always serve as a } \\
\text { role model. She was young, passionate about science, very } \\
\text { knowledgeable and very friendly (Lisa, autobiography) }\end{array}$ \\
\hline & Philosophy & $\begin{array}{l}\text { Inquiry-based science, simulations and virtual labs, field-studies, and } \\
\text { group-work and experimentation...these are the approaches that are } \\
\text { central to my personal philosophy (Emily, interview) }\end{array}$ \\
\hline & $\begin{array}{l}\text { Subject-matter } \\
\text { knowledge }\end{array}$ & $\begin{array}{l}\text { I received straight As in my science courses...I am very confident in } \\
\text { my content knowledge (Lisa, interview) }\end{array}$ \\
\hline & Emotions & $\begin{array}{l}\text { I was happy to be in class, to engage with science, and to study it at } \\
\text { home (Maria, interview) }\end{array}$ \\
\hline
\end{tabular}


Table 1 continued

\begin{tabular}{|c|c|c|}
\hline Figured world & $\begin{array}{l}\text { Identity } \\
\text { dimension }\end{array}$ & Samples of data \\
\hline \multirow[t]{6}{*}{$\begin{array}{l}\text { Professional } \\
\text { experiences }\end{array}$} & Sense of self & $\begin{array}{l}\text { I would like to think of myself as the one teacher who supports } \\
\text { students to gain an interest in science, who appreciate the value of } \\
\text { science in society, and who inspires them to even think of } \\
\text { themselves as future scientists (Lisa, philosophy of teaching) }\end{array}$ \\
\hline & Positioning & $\begin{array}{l}\text { I believe science is one of the most important subjects because } \\
\text { students acquire knowledge and skills that can apply in their } \\
\text { everyday lives (Jennifer, philosophy of teaching) }\end{array}$ \\
\hline & Agency & I try to be a positive role model for my students (Maria, interview) \\
\hline & Philosophy & $\begin{array}{l}\text { I try to engage my students with investigations and field studies } \\
\text { (Maria, philosophy of teaching) }\end{array}$ \\
\hline & $\begin{array}{l}\text { Subject-matter } \\
\text { knowledge }\end{array}$ & $\begin{array}{l}\text { I find some units really difficult to teach because I don't understand } \\
\text { the concepts myself (Emily, interview) }\end{array}$ \\
\hline & Emotions & $\begin{array}{l}\text { I want my students to enjoy science...I want to see them smile in } \\
\text { class and be excited about the lesson (Lisa, interview) }\end{array}$ \\
\hline
\end{tabular}

I was about 8 years old...we visited an environmental center at a dam. We learned how rainwater was collected. We also took measurements of the temperature and the air quality with the help of two field-scientists. It was an amazing experience because we worked with scientists and we kind of felt like scientists too. (Interview)

It is important to note in the above, the emphasis on the emotions indicated through the word "amazing", which was due to the fact that working with scientists made her feel like a scientist. This implies a sense of relating with scientists and their work, which might have empowered her sense of self as a science learner.

Sharing memories situated within the Figured World of schooling, Maria noted how her interest in science declined when going from elementary to secondary school and then to high school because the teachers used teacher-centered approaches. A quote from her interview exemplifies the nature of experiences she had in elementary school:

We used to examine topics such as the relationship of humans with nature, the negative impact of humans on the environment, the protection of the environment and others. These were all very interesting because the teacher would ask us to share our own experiences, and we would always engage in classroom discussions. (Interview)

Two things are important to notice in this quote: the curriculum and the teacher's practices, who provided opportunities for engagement in discussions and who also connected science with the students' own experiences. Going to secondary school, Maria had a whole different experience with science, which resulted in her starting to not like science:

I started disliking science. Each year I liked science less and less. This was because our teachers used teacher-centered approaches. The book included many experiments but our teachers used to perform the experiments in front of the classroom and we 
had to simply report our observations in our notebooks...there were no classroom discussions...overall, there was too much writing (Interview)

Like with the preceding quote, the impact of the teacher's practices on her interest in science becomes apparent. However, it was not just the teaching approaches that put Maria off. It was also, evident in her words, the personalities of the teachers as well as the nature of the learning environment:

Our second science teacher was even worse! Another older man who looked like Einstein; that's how we called him...he was obsessed with Physics and considered it superior to all other disciplines. He would usually talk and talk and talk and we had to just write and write and write, and to memorize a bunch of theories! (Interview)

Another interesting finding emerges from this quote through the phrase "older man who looked like Einstein" which points to science stereotypes but might also imply the role of gender identity in filtering these experiences. A shift on Maria's identity trajectory occurred in the last year of high school because of a young female physics teacher:

She was the best teacher I ever had. She was very enthusiastic and caring. She was friendly with everyone, and used a lot of examples from every day life which made the content very interesting...but, most importantly, she was supportive and made us feel that we could learn it...so, I felt confident again in doing science! (Autobiography)

This excerpt provides further evidence about the possible role of gender identity, even though not explicitly recognized. It is important to notice how Maria used the words "young, female" to describe this teacher as the "best" she ever had, and who supported her in boosting her confidence as a science learner. A question that emerges is whether the same impact would have been described had this teacher been a male or whether the impact were so great because Maria, as a woman, was better able to relate with this female instructor? This becomes even more interesting when exploring Maria's experiences in the Figured World of university, which involved strict male teachers who used teachercentered approaches. In her own words:

Unfortunately, we never got the chance to carry out any experiments because the professor got to do demonstrations in front of the class. Again, lots of writing and memorization of information...the professor was an older man always in a suit...very strict, much like the teachers I had in my early years in high school. (Interview)

Similarly with the preceding excerpts, besides the reference to the teacher-centered approaches, the possible role of gender identity emerges again. However, one cannot be certain whether gender alone is a critical factor, given that in all cases the male instructors were those who exhibited stereotypical personal characteristics and used teacher-centered approaches. Interestingly, Maria had not lost interest in science due to those experiences, however she filtered the experiences through the lens of her strong sense of self as a future science teacher. As she said in the interview, "I had not lost my interest in science, I still found the content interesting, but by this point I knew what kind of a teacher I wanted to be".

Situated within the Figured World of professional experiences, Maria commented on how she tries to be a motivating and inspiring teacher for her students, unlike most of the teachers that she had in her schooling years: "I try to be a positive role model for my 
students. I am always enthusiastic, I express my passion for science, and I try to nurture this passion in them as well". This provides evidence of her sense of agency as a science teacher. In her personal philosophy, she emphasized the importance of an active engagement with students as well as connecting science with everyday life:

I try to engage my students with experimentation, investigations and field studies... and I always try to connect the content with everyday life...to illustrate how scientific concepts apply to our everyday lives. (Autobiography and Personal philosophy)

These ideas can be traced back to Maria's similar science experiences as a learner of science, as indicated through the emphasis on science engagement and connecting science with everyday life. However, it was not easy for her to apply these ideas in practice because of the lack of resources at her school context. A quote from the interview where she reflects on her experiences situated in the Figured World of professional experiences illustrates this:

Most schools do not have laboratories or the necessary scientific and technological equipment...however, I try to use simple materials for experimentations, and of course I make good use of the surrounding environment and possibilities for fieldstudies...it is not easy, but it is possible if you really want to be the teacher you once aspired to be. (Interview)

In summing up Maria's life-story, a few findings stand out: Maria had a strong sense of self as a science learner and she currently has a strong self as a teacher of science. She positioned herself positively towards science throughout her identity trajectory despite the negative science experiences in the Figured World of schooling. This might suggest that by the time she had those experiences, Maria had already developed a strong science identity because of the strong positive influences of a family which supported her to not only not be discouraged by the negative schooling experiences but to also learn from those. Interestingly, even though Maria filtered specific experiences through a gender lens or her gender identity, that did not seem to be explicitly acknowledged by her given that ideas about supporting girls' participation in science did not make their way into her personal philosophy of science teaching and learning.

\section{Emily}

Emily is 23 years old, a first-year elementary teacher who did not specialize in science during her preparation. She positions herself positively towards science and describes herself as a nature-lover with a great curiosity about the natural world. As evident through the analysis of her autobiography, her family influences, situated in the Figured World of family and childhood reinforced this curiosity: "I used to watch a lot of documentaries about animals with my parents, and to plant seeds, observing them as they grew up". When sharing her memories of science during her childhood she noted that she felt different as a girl who liked science:

My friends thought my interests were strange so I felt different...girls don't play with soil, they don't make kites, they don't ride bikes, they don't dismantle their dolls to observe their body parts...but I didn't care what they thought of me...my parents never discouraged me so I didn't feel I was doing something that I wasn't supposed to be doing. (Autobiography) 
This quote is especially interesting because it makes reference to what girls are supposed to do or not to, which implies certain societal gender stereotypes. What is perhaps more important to notice is a strong and explicit stance towards those stereotypes through the phrase "I didn't care". Why? Because, as Emily added in a later section of her autobiography, her parents never discouraged her, which might imply how family capital influences the development of young girls' science identities.

Elaborating on her experiences with science within the Figured World of schooling, Emily described herself as a passive learner of science because her teacher enacted teachercentered approaches. An excerpt from her autobiography illustrates this: "I can remember very vividly how the teacher always standing behind a counter showing us either images of the human body or replicas of human organs". An exemption to this was her fifth-grade teacher who engaged students in experimentation:

I will always remember a very unique teacher, a young, energetic, dymanic man with passion for science and love for his students. This teacher helped me gain back my confidence as a learner of science. He would usually have us work in small groups experimenting with real materials, and would just go around the classroom giving feedack. He tried to engage all students in discussion and was really good at explaining difficult concepts in a very simple manner...and, always drew examples from real life. (Autobiography)

In the above excerpt, there is an emphasis on the teacher's use of innovative approaches that actively engaged students in activities, which contrasts to Emily's prior learning experiences, where she described herself as a "passive learner" of science. What's also clear in this excerpt is that Emily articulated specific attributes for this "unique" teacher: young, energetic, dynamic with passion for science and love for his students. It is interesting to notice how these attributes relate to affective domains of learning (i.e., love for his students), to the teacher's positioning towards science (i.e., passion for science), to the teacher's pedagogical knowledge (i.e., ability to explain difficult concepts in a simple manner) as well as to personal characteristics (i.e., young and dynamic). This provides evidence of Emily's perception of the complexity of a teacher's science identity as well as who she considers to be an excellent science teacher, and probably who she aspires to be.

Talking about her experiences situated in the Figured World of university, she shared positive memories that included instructors who used a variety of innovative approaches and content knowledge that was relevant:

I enjoyed all my science courses at the university because the instructors combined lectures with practical work, and mostly inquiry-based science and experimentation...we studied electricity, magnetism...stuff that we would have to teach in the future,so all students thought that the content of the courses was useful and relevant. (Interview)

A choice of words in this quote that might be relevant to this analysis is the word "enjoyed", which might possibly imply the role of emotions or emotional labor (i.e., science learning is enjoyable) in the development of a science identity. When asked to comment on the various approaches that were used by the instructors, Emily emphasized inquiry-based science and the role of evidence in science:

One of our instructors placed a lot of emphasis on the role of evidence in inquirybased science... she kept asking us to provide evidence for every conclusion we would come up with...I never really realized how important that was, you 
know...and because of that experience, I now apply this to my own practices. (Interview)

A few things are interesting in this quote. One is that it appears that Emily had started to develop an understanding about the importance of teaching science as inquiry, and the other one is that this idea features centrally in both her personal philosophy as well as her instructional practices. This is important especially when viewed in light of literature pointing to challenges and difficulties that beginning elementary teachers face in understanding and enacting science education reform-recommendation (Avraamidou 2017). Sharing her personal philosophy of science teaching within the Figured World of professional experiences, Emily emphasized the active engagement of students and of making science enjoyable for students:

Most students come to school not liking science, some of them because they don't feel confident as learners of science, and others because they find it boring and don't see the value of it. So, I try to make my teaching fun and engaging for all students. In order to encourage them to see the value of science, I always use examples from reallife, just like my teacher at fifth-grade did...in a way, I guess he still serves as a role model for me. (Personal philosophy)

A few ideas are interesting in this excerpt. First, the emphasis on "enjoyment" and "fun", which can be traced back to Emily's experiences in teacher preparation and which also suggests her attention on how emotions might influence learning. Second, is how Emily emphasized the use of examples from real-life, which she experienced in elementary school as a young learner of science. This is very important because it provides evidence of how various experiences throughout a teacher's life are relational, they intersect and influence the development of a teacher's science identity. Not surprisingly, as an elementary teacher, Emily noted that she is not confident in her science content knowledge:

I find some units really difficult to teach, because I don't understand the concepts myself. For example, concepts related to energy. We did not learn about energy at university so I had to do a lot of reading to teach that unit. Still, I was not able to provide clear explanations... In some instances I think I confused students. (Interview)

This excerpt reveals how Emily lacks confidence in terms of her science content knowledge, which is in agreement with related literature about beginning elementary teachers (Davis et al. 2006).

Summing up this case, a few things are important to highlight. Despite the fact that Emily perceives herself as lacking content knowledge, she is positively positioned towards science and science teaching, which is not common for beginning elementary teachers (Davis et al. 2006). Her science identity includes developing understandings about inquirybased science and a sense of agency for supporting students in developing an interest in science. As a young girl, she was perceived to be "different" by her friends because she was not doing what was socially expected; ideas connected to gender science stereotypes. However, that was not discouraging because of her strong family capital with parents who supported her interests and choices. Interestingly, the issue of gender stereotypes did not surface in the data again and ideas related to girls' engagement with science were not included in Emily's personal teaching philosophy or how she views herself as a future science teacher. 


\section{Jennifer}

Jennifer is 22 years old, a recent graduate in elementary education with a specialization in science. She has limited teaching experiences as a substitute teacher. She positions herself positively towards science and science teaching, with strong content knowledge but not srong pedagogical knowledge. In her autiobiography, Jennifer pointed to the influences situated in the Figured World of family in nurturing a love for the natural world. Specifically, she described the influence of her aunt who was a scientist:

I remember visiting my aunt at work and asking her to show me what she does. She took a big container that was a model of a garden with butterflies and asked me to observe them with the use of a magnifying glass. Specifically, she asked me to observe their bodies, their antennas, and the different colors... it was so fascinating to me! (Interview)

This quote is of interest not only because it provides evidence of the significant influence of this family member on Jennifer's development of an interest in science, but because this family member is a woman. Even though Jennifer did not make explicit references to gender issues at this point, when describing her experiences within the Figured Worlds of schooling and university, she described her instructors as "typical older men". The references to these experiences might suggest that Jennifer was filtering these experiences through the lens of her gender identity, even though this was not explicitly articulated.

When describing her science learning experiences situated in the Figured World of schooling, Jennifer was able to recall a number of positive experiences in elementary school, which involved experimentation. An excerpt from her autobiography illustrates this:

I remember a little experiment we did in sixth grade divided into groups; we had tubes in which we added liquids and heated them to see what would happen. It was really exciting because it was the first time we used scientific tools, and actually, it was the first time we conducted an experiment instead of simply observing the teacher carrying out an experiment. (Autobiography)

It's important to notice in these excerpts specific words that suggest Jennifer's emotional trajectory as a science learner, such as "really exciting", a result of this first-time experience of being actively engaged in experimentation. Talking about the same teacher, in her interview, she pointed to his personality characteristics:

He was my favorite teacher. Not only because he had amazing teaching skills but also because he was very caring and had a sense of humor. He was able to make the learning environment joyful and the lessons fun because of his personality and sense of humor. (Interview)

Again, in this quote specific dimensions of this science teacher's practices come to surface, such as his pedagogical knowledge but also how he cared for his students, which could directly impact students' emotional trajectories. Other words that indicate attention to affective domains of learning are "joyful" and "fun", which point to students' positive emotions as a result of this teacher's personality and practices. In contrast to these experiences, when sharing her memories from high school years, Jennifer described her physics teacher as "strict" and "weird": 
He looked like the mad scientist...he was weird. He was an older man who wore very big glasses and overall had a messy look...he was very strict and followed teachercentered approaches in all lessons. (Interview)

It is clear in this quote that Jennifer was able to identify specific social stereotypes about scientists, in which gender surfaced again within the phrase "older man". Jennifer's only positive memories were related to her biology teacher because he supported her in gaining self-confidence as a learner of science:

He was a really cool teacher, young, and had a great sense of humor. I wasn't a good student but he helped me gain confidence in myself, supported me in trying, and never offended me. (Autobiography)

Similar to how Jennifer described her elementary teachers, in the description of her biology teacher she emphasized characteristics related to his personality but she also made references that related to how she viewed herself as a science learner as well as her emotional trajectory. This is evident through the phrases: gained confidence, supported me, and never offended me. Jennifer also described this teacher as the only one who used student-centered approaches in his practices:

We were always engaged in the lesson, carrying out experiments, or engaging in a whole classroom discussion. We found what we were learning interesting things because the teacher would always use examples from real life, so we could see the application of the concepts and find meaning. (Autobiography)

It's important to notice here the emphasis on active engagement with science and connecting science with real-life examples. When asked to describe her experiences as a science learner in the Figured World of university, Jennifer did not have much to say. She described all of her courses being taught either through lectures or through demonstrations of experiments by the instructors:

All my science courses and professors were alike. A typical course was taught at a large amphitheater. The professor, typically, was an older man who didn't care about the learning environment but just wanted to do the lesson and leave; using traditional methods like lectures and demonstrating experiments behind his desk. (Interview)

Quite a few things are important to notice here. Apart from the references to teachercentered approaches and the lack of the professors' attention towards the development of engaging learning environments, it is important to address the implicit references to the professors' personalities (i.e., do the lesson and leave implying not caring for the students) and the phrase "older man". These are consistent with Jennifer's descriptions of other teachers she had within the Figured World of schooling, who differed significantly in terms of personality characteristics and the nature of instructional practices. Jennifer's experiences found their way into her science teaching philosophy, which provides evidence of the impact of this early-life experience as a science learner on the development of her science identity. The first piece of evidence is found in her personal philosophy:

I believe science is one of the most important subjects because students develop knowledge and skills that can apply to their every day lives and that are needed to be active citizens. (Personal Philosophy) 
This excerpt also provides evidence of Jennifer's strong positioning towards science and science teaching. Besides this positioning, Jennifer, also described herself as a confident teacher, which is attributed to her advanced science content knowledge: "science, biology, chemistry, physics and environmental education were my favorite subjects because I was really good at them. I feel confident in doing and teaching science". Elaborating on her views about science teaching, she pointed out that her main goal is to make her students love science:

My biggest concern is that students are not motivated to learn science. So, my main goal is to make science teaching interesting and fun...I want to make them love science. (Interview)

The goal of making science interesting and fun can probably be traced back to Jennifer's science learning experiences situated in the Figured World of schooling, as mentioned earlier, and points to her attention to affective domains of learning. The reference to experimentation also can be traced back to her own science learning experience, and which she also emphasized as part of her personal philosophy of science teaching:

I am a big fan of experimentation...my only memories of science as a young learner are the ones that involved experimentation. So, I am hoping to be able to use a lot of experiments in my future classroom. (Personal philosophy)

In summing up Jennifer's story, it becomes clear how the way she views herself as a science teacher can be traced back to her experiences as a science learner, especially those situated in the Figured World of family and the Figured world of schooling. What makes her story different than the rest is that her experiences in the Figured World of university were negative, due to teacher-centered approaches and strict professors. However, as evident in her words, these experiences didn't negatively impact her interest in science, which she maintained throughout her graduation. A possible explanation for this is that by that time Jennifer had already developed a strong sense of self as a science teacher and was able to filter out these negative experiences. Specific dimensions of her science identity, which surfaced throughout her story, are associated with science content knowledge, emotions, and a strong sense of agency for engaging students in science.

\section{Lisa}

Lisa is a more experienced elementary teacher with 5 years of teaching experience and who has specialized in science during her teacher preparation. She described herself as a passionate and confident science teacher who is well-liked by her students. In sharing her personal story in relation to science, she emphasized the impact of experiences situated in the Figured World of family, and especially of her mom on her decision to become a science teacher. She stated during the interview:

For as long as I can remember, I have always wanted to become a teacher because my mother is a schoolteacher. She greatly influenced me because she was very passionate about teaching; she was a role model for me. (Interview)

Apart from the influence of her mother, Lisa described a visit to a science center with her family, as the most memorable science experience of her life: 
One of my most memorable experiences with science was a visit to a science center with my family. I was so excited. It felt like a huge science playground where you could carry out experiments about many different concepts (Autobiography)

These two excerpts from the data merely provide a snapshot of an important finding that was revealed through the data analysis: Lisa had a rich family capital with many opportunities to experience science outside of school. A related experience situated in the Figured World of childhood/family was watching documentaries. Lisa wrote in her autobiography:

I was always fascinated by documentaries; as a child I don't remember myself watching cartoons on TV, but I remember watching documentaries about the natural world with my parents (Autobiography)

The emphasis on out-of-school science experiences was evident when analyzing data about Lisa's experiences situated in the Figured World of schooling, as well. For example, when sharing her memories of science in elementary school, Lisa described a field-study to a planetarium:

One of my most memorable experiences as a young science learner was a visit to the Planetarium, as part of a field study at school. I was so excited to use telescopes but also the computer application with the virtual sky, the interactive star map. (Autobiography)

Similar to the descriptions of other experiences outside school, this one also included words that point to Lisa's emotional trajectory as a science learner, as evident in the word "excited", which was used a few times. Beside the field-study, Lisa described negative experiences with science in the Figured World of schooling. For example, she described teacher-centered approaches in elementary school:

The teacher would ask us to read some pages from the book and then he would provide a further explanation about what we were reading. And then, we had to fill out the worksheets...too much writing. (Interview)

Teacher-centered approaches were also prevalent in high school and impacted Lisa's positioning towards science, as she began to dislike science:

Teaching included lots of lecturing, assignments and exams...there was never enough time for classroom discussions or experimentation...I started to dislike science then because I felt all this pressure to perform well in exams. (Autobiography)

Interestingly, Lisa shared the specific characteristics of her teachers as negative experiences:

I remember this teacher in fifth grade, a very strict and formal teacher who never asked us to share our views or background knowledge or experiences with science...he was so strict, and unapproachable. I was scared to express my opinion! (Autobiography)

This excerpt has a lot of commonalities with the ways in which Emily and Jennifer described some of their teachers as being "strict and unapproachable". Interestingly, while this teacher was male, Lisa did not make any explicit comments about his gender, which probably suggests that she did not filter these experiences through her gender-identity. Another interesting phrase in this excerpt is the following: "I was scared", which indicates 
Lisa's emotional labor as a science learner in this specific classroom. However, a shift on Lisa's identity trajectory as a science learner occurred within the Figured World of university, where she experienced science as an active learner:

Going to university, I started enjoying my science courses because, as a learner, I was actively engaged through experimentation and group discussions. (Interview)

An additional reason for this shift was the range of topics studied in the methods course which Lisa found interesting:

The methods course was especially interesting because it touched upon a variety of issues connected to science like culture, history of science, the role of women in science and the role of science in everyday life. (Autobiography)

Interestingly, in this excerpt Lisa made a reference to a topic of the methods course about the role of women in science, however, as it will become apparent later on, she does not personally pick up on this as a woman in science who could perhaps serve as a role model for young girls in her classroom. This probably suggests, that much like Jennifer, she was not aware that she was filtering these experiences through her gender-identity.

The fact that she enjoyed both the content of the courses but also her instructors, influenced her performance in the courses, and this indicates advanced science content knowledge. She elaborated on this during the interview:

I received straight As in my science courses because I really liked the content of the courses and because I liked the teachers. I felt motivated and inspired by them because they were enthusiastic and used student-centered approaches, such as project-based science and experimentation (Interview)

As Lisa shared, an influential figure on the development of her science identity and vision of self as a future science teacher was her methods-course instructor. Not only because this instructor was a great teacher but also because of her personality. An excerpt from Lisa's autobiography illustrates this:

A university instructor stands out for me and will always serve as a role model. She was young, passionate about science, very knowledgeable and very friendly. She used different teaching approaches such as inquiry-based science, documentaries, quizzes, science festivals and lots of small group work. She was able to make everyone interested in science and supported everyone, especially the weaker students, to engage in activities. (Autobiography)

Quite a few things are of interest in this excerpt. Firstly, the fact that this instructor was female but Lisa did not comment on that, as is also evident in other data reported earlier. Secondly, Lisa makes references not only to this instructor's practices but also to personal characteristics: young, passionate, friendly and able to make everyone interested, especially weaker students. These attributes and characteristics are directly related to the nature of a learning environment that this teacher probably managed to create, as well as the kinds of interactions (i.e., friendly) she had with her students, which are all directly related to students' emotional trajectories as learners of science. One could, hence, argue that these data might provide evidence of how centrally emotions feature in the development of Lisa's science identity.

When sharing her vision of self as a science teacher, it became evident how these experiences in the Figured World of university had influenced Lisa's views about her role 
as a science teacher, and her sense of agency, especially when related to students' positioning and emotions towards science:

Quite a few of my students come to class with negative attitudes towards science. Hence, my first goal as a science teacher is to support them in gaining interest in science. (Interview)

These words are important because they provide evidence of Lisa's attention to affective domains of learning and are in line with her own experiences as a young learner of science who enjoyed science. When asked to explain how she aims to achieve this goal, Lisa emphasized the use of inquiry-based science and out-of-school science approaches:

I do that by engaging them in inquiry-based science and lots of field studies, and visits to informal environmental centers. And, it works! After only a couple of weeks, I see how their attitudes towards science start changing and how they engage in activities with much enthusiasm! (Interview)

It becomes apparent in this quote that Lisa was developing a set of reform-minded ideas about science teaching, which she was also applying to her instructional practices. An interesting word choice in this quote is "enthusiasm" which points, as other data have, to emotional domains of science learning. Lastly, describing her vision of self as a science teacher, Lisa emphasized the importance of supporting teachers gain confidence as science learners. Additionally, she spoke of herself as a teacher who inspires her students and nurtures an interest in science:

I would like to think of myself as the teacher who supports students gain an interest in science - students who appreciate the value of science in society - and who inspires them to think of themselves as future scientists. (Personal philosophy)

These quotes provide evidence regarding Lisa's sense of agency, her role as a science teacher and how she viewed herself as a science teacher: one who serves as a source of inspiration as well as a role model for them.

Summing up Lisa's story, it is clear how she viewed herself as a confident science teacher with a great sense of agency in supporting her students' engagement with science with enthusiasm. Central in her personal philosophy of science teaching is the use of inquiry-based and out-of-school science, and making connections between science and everyday life. In summarizing Lisa's science identity trajectory, it becomes clear that experiences situated in the Figured World of childhood/family and the Figured World of out-of-school had a strong influence on her science identity. A negative shift on her identity trajectory was observed during schooling (elementary through high school) because of teacher-centered approaches, followed by her teachers' personalities as well as their inability to create friendly and supportive learning environments. Another shift to her identity trajectory occurred when Lisa experienced science in engaging and exciting ways within the Figured World of university. Also important were the interactions with the methods-course instructor, who, as she said, serves as a role model for her because she taught science with the use of a variety of instructional strategies and was also very supportive with all students. Interestingly, much like Maria, it appears that she might had filtered specific experiences through her gender identity, however, ideas related to genderinclusive practices and girls' participation in science were not found in any of the dimensions of her science identity. 


\section{Science teacher identity as a lived experience: a dynamic process of becoming}

What the stories of Maria, Emily, Jennifer, and Lisa tell us is how complex, multifaceted, situated, continuous and always in the making, a beginning elementary teacher's science identity formation might be. If there is one thing that captures the findings of this study it is that the participants' science identities are multidimensional and that sundry kinds of experiences, events, and interactions impacted their formation. As evident in the analysis of the data, specific dimensions of the participants' science identities emerged within the theoretical framing of science teacher identity as a lived experience. The findings of this study capture the intersection of these teachers' sense of self, sense of agency, knowledge, beliefs about science teaching, emotions, gender, and positioning towards science in the context of various Figured Worlds. In what follows, I elaborate on the findings through a discussion of the implications of this study for theory and teacher preparation.

\section{Dimensions of science teacher identity}

Drawn within the findings of the study and building upon existing literature on science teacher identity, the study offers a working theoretical framework for conceptualizing and examining teachers' science identities as a lived experience. At the heart of the account of this framework is a conceptualization of identity as a dynamic process of becoming instead of a product, and an emphasis on the pathways through which teachers come to form their identities. By conceptualizing identity as a lived experience, emphasis is placed on the affective domains of a science teacher's development and on the ways in which experiences situated in various contexts impact identity development, which points to the cultural and situated nature of a teacher's identity. The proposed framework (Fig. 1) exemplifies the seven dimensions of the participants' identities, as those emerged from the data analysis: sense of self, agency, personal philosophy of science teaching, subject-matter

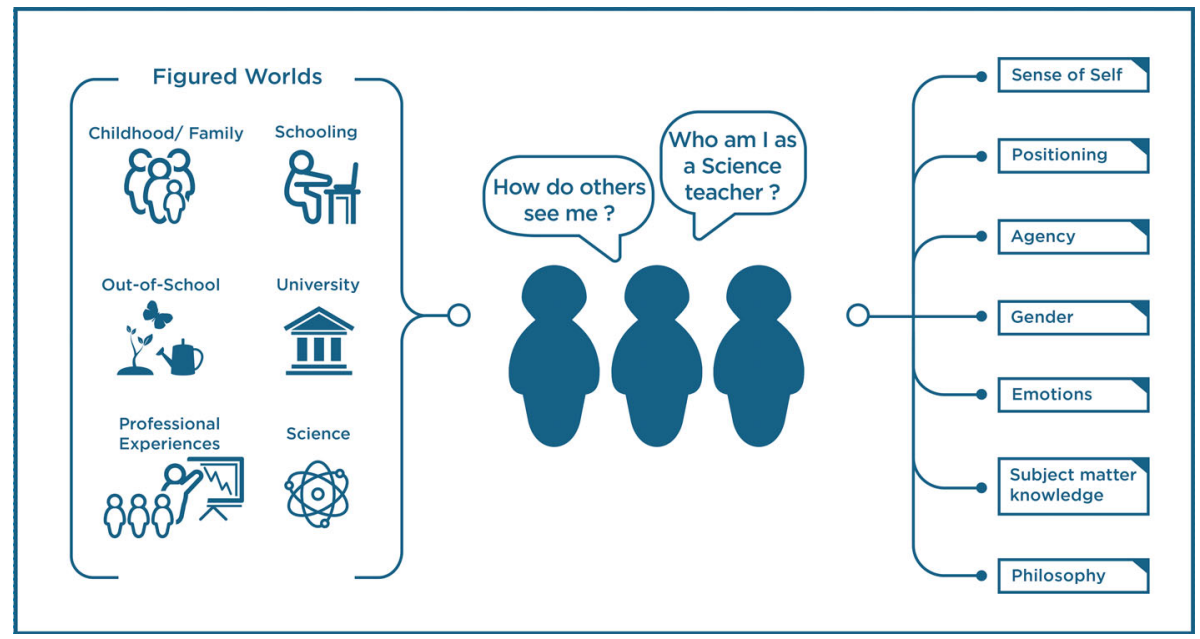

Fig. 1 Science teacher identity as a lived experience 
knowledge, positioning, gender, and emotions. As such, the framework illustrates three main insights: (a) science teacher identity is multidimensional and extends beyond cognitive domains of becoming to include also affective domains; (b) science teacher identity is relational, linked and shaped by various other constructs or sub-identities (e.g., gender identity, personal identity); (c) place and time, defined as a space with meaning created by experiences (e.g., Figured World of family), and science teacher identity are inextricably bound to one another.

These dimensions of science teacher identity have, in fact, been studied independently by other researchers who have argued about their central role in the development of a science teacher's identity. For example, Jennifer Helms (1998) in a qualitative study with five secondary teachers, showed that subject matter is a critical determinant of identity development and illustrated the importance of teachers knowing themselves in respect to their subject matter. Gail Richmond (2016) in a study with preservice science teachers preparing to work in high-poverty schools in the United States, explored the interplay between professional identity and contextual factors and how these contribute to a sense of agency. Moreover, emotions feature as another main dimension of the proposed theoretical model of science teacher identity. Michalinos Zembylas (2005) argued that the ways in which teachers understand, experience, perform, and talk about emotions are related to their sense of identity. Likewise, Maria Rivera Maulucci (2013) who explored the links of emotions and teacher identities in the context of social justice, argued that: "emotions influence the goals teachers set and indicate the intensity of their relationships to ideas, to their beliefs about science, to others, and to science teaching" (p. 137). Positionality, which is used to refer to teachers' positioning towards science as well as their social positioning also features as another main dimension of science teacher identity. As Felicia Moore's research $(2008,2016)$ shows, teachers' views of who they are is directly connected with and essentially defined by multiple social factors such as ethnicity, race, age, religion and gender.

An interesting finding, which however, falls beyond the scope of the study was that two participants seemed to might have filtered specific experiences through their gender identities, even though they were not aware of it as they never explicitly discussed this issue. This points to the main limitation of the study reported in this paper, which included only female participants. However, when designing the study gender was not given special attention hence there were no specific tasks or data collected especially for examining how the participants' gender identities relate to their science identities. Nevertheless, the references made by two of the participants for their teachers as "older men" deserves further attention. Gender and its role to the development of a science identity has featured centrally in various studies that range from examining women scientists' identities (Carlone and Johnson 2007); women of color (Moore 2016), and young girls' participation in science (Brickhouse, Lowery and Schultz, 2000). In a review of the literature about girls and science, Jennie Brotman and Felicia Moore (2008), concluded that the development of science identity is the most recently emerging in the gender and science literature. In summarizing this line of work, the researchers suggested that "schools, as well as society in general, need to make room for identities that defy commonly held, stereotypical norms about both gender and science" (p. 21). 


\section{Science teacher identity: situated, historical, relational, and multidimensional}

Furthermore, the findings of this study highlight the situated nature of science teacher identity as it exemplifies how the science-related life-experiences of a group of female beginning teachers impacted the formation and re-formation of their science identities. The participants of this study were members of various Figured World and communities throughout their lives (e.g., schooling, university, family). Their participation in these communities, as evidenced in the findings of this study, had impacted the formation of their science identities. As documented in my previous work, beginning teachers' life histories are intertwined with their science identities, and specific experiences throughout their lives are critical to their development (Avraamidou 2016b). The findings of these studies showed that beginning teachers learn and develop within a variety of communities and contexts throughout their lives, which illustrates the multifaceted and historical nature of their science identities (Lemke 2008), and highlights the importance of the context on the formation of identity (Wenger 1998, 2000). Lemke (2008) emphasized the situated nature of identity and argued that identity is constructed by interaction and is shaped by the cross section of self and others. This multifaceted, historical, and situated nature of science teacher identity is fundamental in conceptualizing science teacher identity as it considers how different experiences in different Figured Worlds relate and impact teachers' identities. As such, the findings of this study suggest the value of adopting a relationality lens when examining science identity across time and place.

Relationality is influenced by the ethical philosophy of Emmanuel Levinas, which challenges the Cartesian conception of discrete, self-founding subjects, and instead considers the primary of relationships in the constitution of subjectivity. This concept invites us to rethink of our very 'being' in the world and to re-conceptualize identity by integrating multiple identities (e.g., gender identity and science identity) and thereby the individual, interpersonal, and collective levels of self. To do that, as Margaret Somers (1994) argued, we should link the concepts of narrative and identity based on the notion that social life is itself storied. As Somers described, "people construct identities (however multiple and changing) by locating themselves or being located within a repertoire of embodied stories; that experience is constituted through narratives" (p. 614). At the heart of the account of these embodied stories, as surfaced in the findings of this study, are: (a) place which points to the significant role of the Figured Worlds or contexts in shaping a teacher's science identity; (b) time which illustrates the historicity of continuity of identity; and, (c) relationality which suggests the multiplicity of science teacher identity.

\section{Science teacher identity formation and re-formation in teacher preparation}

The findings of the study showed how the four participants' identities were shifted and reformed through teacher preparation, and provide evidence of the significant impact of the elementary methods course. This opens up a new line of questions. Could teacher preparation help beginning elementary teachers reconstruct such negative science learning identities and support them in forming reform-based science teaching identities? Could teacher preparation ever cope with such a challenge? With evidence gathered from this study and building on evidence from existing literature (Avraamidou 2016a), I argue that it 
is possible to support beginning elementary teachers in reconstructing their identities through teacher preparation. This argument, however, is offered with the recognition that this is not a simple task. Instead, I acknowledge the complexity of the process of a teacher's identity formation, which requires careful scaffolding, a combination of a great variety of approaches, strategies, techniques, tools, interactions and assignments.

It became evidenced in the findings of this study that specific aspects and experiences within teacher preparation supported some participants to reconstruct their weak science identities and regain interest in science, and others to develop more reform-minded identities. Three participants pointed to the impact of inquiry-based, small-group work and the nature of the learning environment on their developing ideas about science teaching and learning. One of the participants (Lisa) commented on the nature of her interactions and relations with the methods course instructors, in most cases young, females who contradicted the stereotypical image of middle-aged, strict, male science teachers with whom she had interacted throughout their schooling years. These findings are in agreement with previous research findings pointing to the impact of teacher preparation on the development of beginning teachers and have several implications.

First, it's crucial to understand that science teacher identity has multiple dimensions that go beyond cognitive domains of learning and address these through teacher preparation (Avraamidou 2016a). Second, it's important to pay attention to teachers' emotions and how these interrelate with psychological (e.g., self-efficacy) and cognitive factors (e.g., knowledge) (Zembylas 2005). Third, it is imperative to provide teachers with multiple opportunities for identity shaping (e.g., developing a sense of agency) and re-shaping. This has the potential of making teachers more conscious and aware of who they are and who they are becoming through a process of self-reflection and re-examination of their developing identities. Lastly, as surfaced through the findings of this study and as Noel Enyedy and Jennifer Goldberg (2006) also suggested, it is important to consider how science identity and classroom practice are intertwined, and to examine the two simultaneously in order to understand how identity shapes pedagogical decisions and classroom practice and conversely.

\section{Instead of a conclusion}

This study has sought to understand how elementary teachers' science identities are shaped by their lived experiences across time and place. The findings revealed that the participants' science identities had been in formation from the early years of their lives as learners of science and as members of various communities. Although these findings are useful for gaining an understanding about the processes through which elementary teachers' identities are shaped and re-shaped, further research is needed to determine these processes in different populations of teachers within diverse geographical and sociocultural contexts.

The study hopes to offer a contribution to the increasing knowledge base of science teacher identity at different levels: theoretical, methodological, and practical. The outcomes of this study contribute towards articulating the theoretical concepts and implications of studying science teacher identity as a lived experience through a life-history approach. The idea that science teacher identity is a life-story resonates with sociocultural theory emphasizing the role of time and place on identity development and harmonizes in synergistic ways with the conceptualization of identity as situated, historical, relational, 
and multidimensional. This calls for future research examining teachers' narrative accounts of their science identities, given the potential value of gaining an understanding about the stories that teachers carry with them and how these stories are nested in larger narratives. The question, then, arises: are teachers' stories methodological means to the conceptual end of studying science identity and identity process? Or, are teachers' stories "the thing"? With evidence drawn from this study, I argue that stories can serve both roles.

In a related manner, an understanding of the nature of science teacher identity as historical, relational, and multidimensional suggests studying the intersection of multiple identities in order to increase our comprehension of the different bases or funds of science teacher identity. From a methodological perspective, these insights call for the development of intersectional multi-methodologies that have the potential to capture the multiplicity and complexity of science teacher identity. The paper concluded by considering the relationship between science teacher identity and classroom practice and a proposition that researchers turn their attention at the crossing of science teacher identity and classroom practice. This points to the importance of studying how science teacher identity is performed, or put differently, how science teachers assign meanings to their identities and perform their roles. On a more practical sense, this recommendation speaks to the need for examining the enactment of science teacher identity, found within an investigation of "how teachers view themselves" and "what teachers do". Such an investigation holds promise for contributing to our understanding of time, place, identity, and practice and their implications for each other.

Open Access This article is distributed under the terms of the Creative Commons Attribution 4.0 International License (http://creativecommons.org/licenses/by/4.0/), which permits unrestricted use, distribution, and reproduction in any medium, provided you give appropriate credit to the original author(s) and the source, provide a link to the Creative Commons license, and indicate if changes were made.

\section{References}

Avraamidou, L. (2014). Studying science teacher identity: Current insights and future research directions. Studies in Science Education, 50, 145-179. https://doi.org/10.1080/03057267.2014.937171.

Avraamidou, L. (Ed.). (2016a). Studying science teacher identity: Theoretical, methodological and empirical explorations. Rotterdam: Sense Publishers. .

Avraamidou, L. (2016b). Intersections of life histories and science identities: The stories of three preservice elementary teachers. International Journal of Science Education, 38, 861-884. https://doi.org/10.1080/ 09500693.2016.1169564.

Avraamidou, L. (2017). A well-started beginning elementary teacher's beliefs and practices in relation to reform recommendations about inquiry-based science. Cultural Studies of Science Education, 12, 331-353. https://doi.org/10.1007/s11422-015-9700-x.

Beijaard, D., Meijer, P. C., \& Verloop, N. (2004). Reconsidering research on teachers' professional identity. Teaching and Teacher Education, 20, 107-128. https://doi.org/10.1016/j.tate.2003.07.001.

Brickhouse, N. W., Lowery, P., \& Schultz, K. (2000). What kind of a girl does science? The construction of school science identities. Journal of Research in Science Teaching, 37, 441-458. https://doi.org/10. 1002/(SICI)1098-2736(200005).

Brotman, J. S., \& Moore, F. M. (2008). Girls and science: A review of four themes in the science education literature. Journal of Research in Science Teaching, 45(9), 971-1002. https://doi.org/10.1002/tea. 20241.

Carlone, H. B., \& Johnson, A. (2007). Understanding the science experiences of successful women of color: Science identity as an analytic lens. Journal of Research in Science Teaching, 44, 1187-1218. https:// doi.org/10.1002/tea.20237.

Connelly, F. M., \& Clandinin, D. J. (1999). Shaping a professional identity: Stories of educational practice. New York: Teachers College Press. 
Corbin, J. M., \& Strauss, A. L. (2008). Basics of qualitative research: Techniques and procedures for developing grounded theory (3rd ed.). Thousand Oaks: Sage.

Davis, E. A., Petish, D., \& Smithey, J. (2006). Challenges new science teachers face. Review of Educational Research, 76, 607-651. https://doi.org/10.3102/00346543076004607.

Eick, C. J., \& Reed, C. J. (2002). What makes an inquiry-oriented science teacher? The influence of learning histories on student teacher role identity and practice. Science Education, 86, 401-416. https://doi.org/ 10.1002/sce.10020.

Enyedy, N., \& Goldberg, J. (2006). Complex dilemmas of identity and practice. Journal of Research in Science Teaching, 90, 68-93. https://doi.org/10.1002/sce.20096.

Esteban-Guitart, M., \& Moll, L. C. (2014). Lived experience, funds of identity and education. Culture \& Psychology, 20, 70-78. https://doi.org/10.1177/1354067X13515940.

European Commission. (2015). Science education for responsible citizenship. Brussels: Directorate-General for Research and Innovation, Science with and for Society. http://ec.europa.eu/research/swafs/pdf/pub_ science_education/KI-NA-26-893-EN.pdf.

Gee, J. P. (2000). Identity as an analytic lens for research in education. Review of Research in Education, 25, 99-125. https://doi.org/10.3102/0091732X025001099.

Helms, J. V. (1998). Science-And me: Subject matter and identity in secondary school science teachers. Journal of Research in Science Teaching, 35, 811-834. https://doi.org/10.1002/(SICI)10982736(199809)35:7\%3C811::AID-TEA9\%3E.

Holland, D., Lachicotte, W., Skinner, D., \& Cain, C. (1998). Identity and agency in cultural words. Cambridge: Harvard University Press.

Katz, P., McGinnis, R. I., Hestness, E., Riedinger, K., Marbach-Ad, G., Dai, A., et al. (2011). Professional identity development of teacher candidates participating in an informal science education internship: A focus on drawings as evidence. International Journal of Science Education, 33, 1169-1197. https://doi. org/10.1080/09500693.2010.489928.

Lave, J., \& Wenger, E. (1991). Situated learning: Legitimate peripheral participation. Cambridge: Cambridge University Press.

Lemke, J. L. (2008). Identity, development and desire: Critical questions. In C. R. Caldas-Coulthard \& R. Iedema (Eds.), Identity trouble (pp.17-42). London: Palgrave Macmillan.

Luehmann, A. (2008). Identity development as a lens to science teacher preparation. Science Education, 91, 822-839. https://doi.org/10.1002/sce.20209.

Merriam, S. B. (2009). Qualitative research: A guide to design and implementation. San Francisco, CA: Jossey-Bass.

Moore, F. M. (2008). Positional identity and science teacher professional development. Journal of Research in Science Teaching, 45, 684-710. https://doi.org/10.1002/tea.20258.

Moore, F. M. (2016). Positional identity as a framework to studying science teacher identity: Looking at the experiences of teachers of color. In L. Avraamidou (Ed.), Studying science teacher identity: Theoretical, methodological and empirical considerations (pp. 49-70). Rotterdam: Sense Publishers.

Richmond, G. (2016). Making sense of the interplay of identity, agency, and context in the development of beginning science teachers in high-poverty schools. In L. Avraamidou (Ed.), Studying science teacher identity: Theoretical, methodological and empirical considerations (pp. 219-236). Rotterdam: Sense Publishers.

Rivera Maulucci, M. S. (2013). Emotions and positional identity in becoming a social justice science teacher: Nicole's story. Journal of Research in Science Teaching, 50, 453-478. https://doi.org/10.1002/ tea. 21081.

Siry, C., \& Lara, J. (2012). "I didn't know water could be so messy": Coteaching in elementary teacher education and the production of identity for a new teacher of science. Cultural Studies of Science Education, 7, 1-30. https://doi.org/10.1007/s11422-011-9339-1.

Somers, M. R. (1994). The narrative construction of identity: A relational and network approach. Theory and Society, 23, 605-649. https://doi.org/10.1007/BF00992905.

Tobin, K., \& Llena, R. (2012). Colliding identities, emotional roller coasters, and contradictions of urban science education. In M. Varelas (Ed.), Identity construction and science education research: Learning, teaching, and being in multiple contexts (pp. 141-156). Rotterdam: Sense Publishers.

UNESCO. (2015). Unesco science report: Towards 2030. Paris: United National Educational, Scientific and Cultural Organization.

Upadhyay, B. (2009). Negotiating identity and science teaching in a high-stakes testing environment: An elementary teacher's perceptions. Cultural Studies of Science Education, 4, 569-586. https://doi.org/ 10.1007/s11422-008-9170-5.

Varelas, M. (Ed.). (2012). Identity construction and science education research. Rotterdam: Sense Publishers. 
Varelas, M., House, R., \& Wenzel, S. (2005). Beginning teachers immersed into science: Scientist and science teacher identities. Science Education, 89(3), 492-516. https://doi.org/10.1002/sce.20047.

Wenger, E. (1998). Communities of practice: Learning, meaning, and identity. Cambridge: Cambridge University Press.

Zembylas, M. (2005). Discursive practices, genealogies, and emotion rules: A poststructuralist view on emotion and identity in teaching. Teaching and Teacher Education, 21, 935-948. https://doi.org/10. 1016/j.tate.2005.06.005.

Lucy Avraamidou is Associate Professor at the Institute for Science Education and Communication at the University of Groningen in the Netherlands. She received her Ph.D. from the Pennsylvania State University. Prior to her appointment at the University of Groningen she worked as an Associate Professor at the University of Nicosia, Cyprus, and as a Research Associate at the Center of Informal Learning and Schools (CILS) at King's College London. Her area of concentration is science education and her research is associated with theoretical and empirical explorations of beginning elementary teachers' learning and development with the use of interpretive approaches. 